JPP IPTEK Mei 2019, Vol. 3, No. 1

ISSN 2620-7745 (online)

https://dx.doi.org/10.31284/j.jpp-iptek.2019.v3i1.428

\title{
Pelatihan Penggunaan E-learning Berbasis Media Sosial Edmodo bagi Guru SD Negeri Mulyorejo I Surabaya
}

\author{
Ahmad Hatip ${ }^{1}$, Sucipto $^{2}$, Windi Setiawan ${ }^{3}$ \\ ${ }^{1,2,3}$ Universitas Dr. Soetomo \\ 1ahmad.hatip@unitomo.ac.id, ${ }^{2}$ sucipto@unitomo.ac.id, ${ }^{3}$ windi.s@unitomo.ac.id
}

\begin{abstract}
Based on the description of the situation analysis, the community service activities that will be carried out are training on Edmodo social media-based e-learning for teachers at SD Negeri Mulyorejo I Surabaya. This activity is carried out to provide understanding and skills regarding how to learn with a good e-learning approach. The choice of this type of community service activity illustrates the spirit of the community service of Dr. Soetomo University who wants to contribute actively in the activities of the Indonesian Human Development Index (HDI) improvement program in a sustainable manner with the coverage of all regions in Indonesia. One of the targets to be achieved is the change in attitude and improvement of the skills of partner communities so that teachers from SD Negeri Mulyorejo I Surabaya can use the features of Edmodo social media in obtaining information, developing knowledge and interacting with teachers and students. The training was conducted with lecture methods, slide and video screenings, question and answer, interactive dialogue, brainstorming and work practices. The overall these activities are carried out in a span of 6 months (April-September 2018), starting from the planning, preparation, and implementation stages. The results of community service can be seen from the results of evaluating the processes, products, and participants' responses to the implementation of the training collected through the satisfaction questionnaire. In the process of implementing training, in general, partners have a great willingness and interest to attend training.
\end{abstract}

Keyword: E-learning, Social Media, Edmodo

\begin{abstract}
ABSTRAK
Berdasarkan uraian analisis situasi mitra/masyarakat binaan, kegiatan abdimas yang akan dilakukan adalah pelatihan penggunaan e-learning berbasis media sosial Edmodo bagi guru SD Negeri Mulyorejo I Surabaya. Kegiatan ini dilaksanakan untuk memberikan pemahaman dan keterampilan mengenai bagaimana pembelajaran dengan pendekatan e-learning yang baik. Secara substantif, kegiatan abdimas tersebut memiliki relevansi dengan tujuan abdimas dosen Universitas Dr. Soetomo tahun 2018. Dengan kata lain, ada relevansi antara kebutuhan peningkatan kapasitas masyarakat di lingkungan Universitas Dr. Soetomo dengan sumber daya bidang keilmuan yang dimiliki oleh tim abdimas. Pilihan atas jenis kegiatan abdimas seperti ini menggambarkan semangat pengabdian masyarakat Universitas Dr. Soetomo yang ingin berkontribusi secara aktif dalam kegiatan program peningkatan Indeks Pembangunan Manusia (HDI) Indonesia secara berkelanjutan dengan cakupan seluruh wilayah di Indonesia. Salah satu target yang ingin dicapai adalah terjadinya perubahan sikap dan peningkatan keterampilan masyarakat mitra sehingga guru-guru SD Negeri Mulyorejo I Surabaya bisa menggunakan fitur-fitur pada media sosial Edmodo dalam memperoleh informasi, mengembangkan ilmu pengetahuan, dan berinteraksi dengan guru dan siswa didiknya. Pelatihan dilakukan dengan metode ceramah, pemutaran slide dan video, tanya jawab, dialog interaktif, curah pendapat, dan praktik kerja. Kegiatan abdimas secara keseluruhan dilaksanakan dalam rentang waktu 6 bulan (April-September 2018), mulai dari tahap perencanaan, persiapan, hingga pelaksanaan. Hasil abdimas dapat diketahui dari hasil evaluasi proses, produk, dan respon peserta terhadap pelaksanaan pelatihan yang dikumpulkan melalui angket kepuasan. Dalam proses pelaksanaan pelatihan, pada umumnya mitra memiliki kemauan dan minat yang besar untuk mengikuti pelatihan.
\end{abstract}

Keyword: E-learning, Media sosial, Edmodo 


\section{PENDAHULUAN}

\subsection{Analisis Situasi}

Perkembangan ilmu pengetahuan dan teknologi, khususnya teknologi informasi dan komunikasi (TIK) telah merambah berbagai bidang kehidupan, tidak terkecuali bidang pendidikan dan pengajaran. Kemajuan TIK tersebut, tidak dapat dipungkiri, banyak membawa dampak positif bagi kemajuan dunia pendidikan dewasa ini. Teknologi komputer dan internet, mulai dari perangkat lunak maupun perangkat keras memberikan banyak tawaran dan pilihan bagi dunia pendidikan untuk menunjang proses pembelajaran para peserta didik. Penguasaan terhadap TIK menjadi hal yang sangat penting dalam rangka menghadapi persaingan global. Oleh karena itu, TIK sangat perlu untuk diperkenalkan, dipraktikkan, dan dikuasai oleh pendidikdan peserta didik agar dapat bersaing di dalam kehidupan global

E-learning adalah suatu kemajuan penting dalam sistem pendidikan modern. E-learning ini membawa pengaruh terjadinya proses transformasi pendidikan konvensional ke dalam bentuk digital, baik secara isi (contents) maupun sistemnya. Darin E. Hartley dalam (Mutia, 2013) mengatakan bahwa e-learning adalah suatu jenis belajar mengajar yang memungkinkan tersampaikannya bahan ajar ke siswa dengan menggunakan media Internet. Intranet atau media jaringan komputer lain. E-learning juga dapat didefinisikan sebagai upaya peserta didik dengan sumber belajarnya (basis data, pakar/guru, dan perpustakaan) yang secara fisik terpisah atau bahkan berjauhan. E-learning atau electronic learning kini semakin dikenal sebagai salah satu cara untuk mengatasi masalah pendidikan melalui penerapan TIK.

Edmodo dikembangkan pada akhir tahun 2008 oleh NicBorg dan Jeff Ohara dalam (Basori, 2013) yang berkeyakinan bahwa perlu dikembangkan lingkungan sekolah yang terhubung dengan semua aktivitas di dunia. Edmodo adalah platform media sosial yang sering digambarkan sebagai Facebook untuk sekolah dan dapat berfungsi lebih banyak lagi sesuai dengan kebutuhan. "Edmodo merupakan aplikasi yang menarik bagi guru dan siswa dengan elemen social yang menyerupai Facebook, tapi sesungguhnya ada nilai lebih besar dalam aplikasi edukasi berbasis jejaring sosial ini” (Basori, 2013).

Beberapa fitur yang terdapat pada Learning Management System (LMS) untuk mendukung e-learning seperti penugasan, kuis, dan penilaian pun terdapat di Edmodo. Edmodo sangat komprehensif sebagai sebuah course management system seperti layaknya Moodle, dengan antarmuka (interface) yang menyerupai Facebook yang merupakan media sosial populer saat ini. Pengguna tidak akan merasa asing, bahkan akan merasa mudah untuk menggunakannya (Suriadhi, 2014).

Fakta yang ada di lapangan, kemampuan penggunaan TIK pada bidang pendidikan di negara berkembang seperti Indonesia tentu tidak akan sebaik kemampuan TIK tenaga pendidik di negara maju (Hidayat, 2014). Dengan demikian, persoalan kelemahan tenaga pendidik dalam menggunakan TIK akan dijumpai di mana saja di Indonesia, termasuk di Jawa Timur. Dengan manfaat yang begitu banyak, penggunaan e-learning dalam proses belajar mengajar di sekolah dasar sangatlah rendah. Di sisi lain, penggunaan e-learning dalam proses belajar mengajar ini sangatlah berbanding terbalik dengan penggunaan media sosial oleh guru dan siswa di sekolah dasar. Dalam kesehariannya, baik di sekolah maupun di rumah, guru maupun siswa kerap sekali menggunakan media sosial, seperti Facebook, Twitter, Path, dan lain-lain untuk berinteraksi, berbagi informasi, bahkan membicarakan seputar pembelajaran di sekolah (Yazdi, 2012) .

Berdasarkan pemaparan tersebut, pengenalan dan penggunaan media sosial Edmodo bagi guru sekolah dasar dalam proses belajar mengajar sangatlah tepat untuk dilakukan. Keterampilan penggunaan media sosial yang dimiliki oleh guru tentu akan sangat mempermudah proses pembelajaran dengan menggunakan Edmodo yang memiliki keunggulan serupa dengan aplikasi $e$ - learning pada umumnya.

Pemanfaatan internet sebagai sarana pendidikan yang kerap dilakukan adalah melalui media e-learning. Indonesia merupakan negara dengan jumlah penduduk pengguna internet terbanyak di Asia Tenggara. Akan tetapi, berdasarkan survey yang dilakukan oleh Asosiasi Penyelenggara Jasa Internet Indonesia (APJII) yang bekerja sama dengan Pusat Kajian Komunikasi (Puskakom) Universitas Indonesia mengenai profil pengguna internet Indonesia tahun 2014, 
diperoleh data bahwa penggunaan internet di Indonesia sebagai sarana pendidikan hanya 29,3\% (Indonesia, 2015).

Hal tersebut terjadi karena lemahnya pengetahuan serta keterampilan penggunaan internet, khususnya e-learning, sebagai media pendukung pendidikan. Lemahnya pengetahuan serta keterampilan ini terjadi di hampir seluruh wilayah Indonesia, termasuk Jawa Timur.

Berbanding terbalik dengan penggunaan internet sebagai sarana pendidikan, berdasarkan survei yang dilakukan APJII tahun 2014, ditemukan data bahwa 87,4\% penduduk Indonesia menggunakan internet untuk mengakses media sosial. Sebesar $43,7 \%$ pengguna internet di Indonesia adalah pengguna kalangan pelajar dan guru (Indonesia, 2015). Hal ini merupakan indikasi bahwa penggunaan media sosial telah menjadi suatu budaya dalam kehidupan pelajar sehingga merupakan suatu tantangan bagi pendidik untuk menggunakan strategi dengan memanfaatkan kultur tersebut. Dari hasil wawancara dengan beberapa guru serta siswa di SD Negeri Mulyorejo I Surabaya, sebagian besar tidak mengetahui adanya media sosial Edmodo sebagai salah satu aplikasi e-learning yang dapat digunakan dalam mendukung proses pembelajaran dan berinteraksi dengan guru atau siswa lain layaknya media sosial yang ada.

Dari proses wawancara, juga diperoleh informasi tidak adanya media yang dapat digunakan sebagai sarana berinteraksi antarguru, antarsiwa, atau antarguru-dan-siswa di SD Negeri Mulyorejo I atau cakupan yang lebih luas, dalam berbagi pengetahuan, informasi, dan atau konten pembelajaran. Dari proses observasi yang dilakukan di SD Negeri Mulyorejo I Surabaya, sarana yang dimiliki sekolah sangatlah mendukung proses pembelajaran menggunakan e-learning berbasis media sosial Edmodo ini, seperti adanya komputer dan hotspot di lingkungan sekolah. Guru dan siswa SD Negeri Mulyorejo I pada umumnya juga sudah terbiasa dalam penggunaan laptop atau komputer dalam kegiatan sehari-hari. Berdasarkan data dan informasi tersebut, dipandang perlu untuk memberikan pelatihan penggunaan e-learning berbasis media sosial Edmodo ini bagi guru dan siswa Kelas V SD Negeri Mulyorejo I Surabaya. Dari proses wawancara dan observasi yang dilakukan, hampir sebagian besar guru di SD Negeri Mulyorejo I Surabaya merupakan pengguna aktif media sosial seperti Facebook sehingga pelatihan penggunaan media sosial Edmodo ini diharapkan dapat berjalan secara efektif dan dapat diterapkan dengan baik di sekolah mengingat cara penggunaan Edmodo yang hampir mirip media sosial Facebook.

\subsection{Identifikasi Masalah}

Berdasarkan hasil observasi dan wawancara yang telah dilakukan kepada Kepala Sekolah SD Negeri Mulyorejo I Surabaya dan beberapa orang guru, dapat diidentifikasi permasalahan sebagai berikut.

1. Belum tersedianya fasilitas e-learning di sekolah;

2. Kurangnya pengetahuan guru tentang keunggulan e-learning berbasis media sosial Edmodo;

3. Kurangnya keterampilan guru dalam penggunaan e-learning berbasis media sosial Edmodo;

4. Belum tersedianya fasilitas bagi guru SD Negeri Mulyorejo I Surabaya untuk dapat berinteraksi dalam berbagi informasi maupun berbagi pengetahuan.

Berdasarkan identifikasi permasalahan tersebut, dapat dirumuskan permasalahan yang ingin dipecahkan yaitu bagaimana memberikan pengetahuan dan keterampilan bagi guru di SD Negeri Mulyorejo I Surabaya dalam menggunakan e-learning berbasis media sosial Edmodo.

\subsection{Tujuan dan Manfaat}

\section{a. Tujuan Kegiatan}

Tujuan pelaksanaan kegiatan abdimas ini adalah untuk memberikan keterampilan penggunaan e-learning berbasis media sosial Edmodo bagi guru SD Negeri Mulyorejo I Surabaya. Khalayak sasaran yang dilibatkan dalam pelatihan ini sebanyak 20 orang guru. Tujuan utama kegiatan pelatihan ini adalah: 
1. memberikan pengetahuan mengenai e-learning berbasis media sosial Edmodo kepada guru SD Negeri Mulyorejo I Surabaya;

2. memberikan keterampilan penggunaan media sosial Edmodo kepada guru SD Negeri Mulyorejo I Surabaya;

3. memberikan keterampilan penggunaan atau pengelolaan fitur-fitur pada media sosial Edmodo dalam pengemasan materi pembelajaran yang disusun oleh guru di SD Negeri Mulyorejo I Surabaya; dan

4. memberikan keterampilan penggunaan fitur-fitur pada media sosial Edmodo dalam memperoleh informasi, mengembangkan ilmu pengetahuan, dan berinteraksi dengan guru SD Negeri Mulyorejo I Surabaya.

\section{b. Manfaat Kegiatan}

Hasil kegiatan pengabdian kepada masyarakat ini diharapkan akan memberikan kontribusi positif untuk meningkatkan profesionalisme guru SD Negeri Mulyorejo I Surabaya dalam mengembangkan serta menyebarluaskan ilmu pengetahuan, teknologi, dan seni. Secara lebih rinci, manfaat dari kegiatan abdimas ini adalah sebagai berikut.

1. Guru SD di Kecamatan Mulyorejo Surabaya memperoleh wawasan mengenai e-learning berbasis media sosial Edmodo.

2. Guru SD di Kecamatan Mulyorejo Surabaya mampu menggunakan media sosial Edmodo.

3. Guru SD di Kecamatan Mulyorejo Surabaya mampu mengemas materi pembelajaran yang lebih inovatif, efektif, dan efisien dengan menggunakan media sosial Edmodo.

4. Guru SD Negeri Mulyorejo I Surabaya memiliki interaksi pembelajaran yang lebih luas dan multi-sumber belajar.

\section{METODE PELAKSANAAN}

Metode kegiatan yang dilakukan dalam pengabdian kepada masyarakat ini adalah dalam bentuk ceramah, diskusi, dan praktik. Pelatihan akan dilakukan 6 bulan (April-September 2018) yang berfokus dalam memberikan informasi mengenai pemanfaatan e-learning, pengenalan Edmodo, proses mendaftar di Edmodo, sampai pada pengenalan fitur-fitur dan keunggulan Edmodo. Pelatihan berikutnya akan difokuskan pada pengemasan konten pembelajaran serta pelaksanaan praktik dan simulasi proses pembelajaran dengan memanfaatkan fitur-fitur yang ada pada Edmodo.

\subsection{Strategi dan Metode}

Kegiatan abdimas dilakukan dalam bentuk workshop pelatihan dan pendampingan penerapan pembelajaran yang berbasis pada media sosial Edmodo. Untuk itu, strategi pelaksanaan kegiatan meliputi langkah-langkah sebagai berikut.

a. Berkoordinasi dengan mitra, dalam hal ini Kepala Sekolah SD Negeri Mulyorejo I Surabaya. Pada tahap ini, dibahas tentang kebutuhan mitra, alat dan bahan, tempat pelaksanaan abdimas, waktu pelaksanaan, instruktur atau narasumber, serta rencana biaya operasional kegiatan abdimas.

b. Mendatangi Ketua Mitra di SD Negeri Mulyorejo I Surabaya, membicarakan waktu pelaksanaan kegiatan.

c. Berkoordinasi dan pembagian tugas dengan anggota tim abdimas.

d. Melakukan persiapan, meliputi:

- penyusunan bahan untuk pelatihan

- penyiapan daftar hadir peserta

- pembelian alat dan bahan untuk perangkat atau lembar kerja

- penyusunan angket kepuasan

- pemesanan spanduk kegiataan abdimas 
- penyiapan laptop dengan menghubungi pihak persewaan

- pendokumentasian: video dan kamera

- pemesanan konsumsi: snack dan air mineral

e. Melaksanakan kegiatan abdimas sesuai dengan waktu yang disediakan.

Agenda kegiatan abdimas disusun berdasarkan target hasil yang akan dicapai. Secara keseluruhan, rangkaian kegiatan abdimas dilakukan dalam urutan langkah yang disusun dalam jadwal kegiatan pada Tabel 1.

Tabel 1. Jadwal Kegiatan Abdimas

\begin{tabular}{|c|c|c|c|}
\hline Pertemuan & Target & Materi & Pelaksana \\
\hline $\begin{array}{l}\text { Pertemuan ke-1 } \\
21 \text { April } 2018\end{array}$ & $\begin{array}{l}\text { Penyurveian } \\
\text { Lokasi }\end{array}$ & \begin{tabular}{ll}
\multicolumn{2}{l}{ Penentuan: } \\
- $\quad$ bentuk kegiatan \\
- tempat pelaksanaan \\
- waktu kegiatan \\
- materi kegiatan \\
- alat dan bahan \\
- instruktur/narasumber
\end{tabular} & Tim Abdimas dan Mitra \\
\hline $\begin{array}{l}\text { Pertemuan ke-2 } \\
19 \text { Mei } 2018\end{array}$ & $\begin{array}{l}\text { Persiapan } \\
\text { Kegiatan }\end{array}$ & $\begin{array}{l}\text { Persiapan: } \\
\text { - } \text { menyusun materi pelatihan } \\
\text { - } \text { menyiapkan tempat } \\
\text { - } \text { memesan spanduk } \\
\text { - melakukan pengadaan alat dan } \\
\text { bahan } \\
\text { - memesan kendaraan ke rental } \\
\text { - memesan snack dan air mineral }\end{array}$ & Tim Abdimas dan Mitra \\
\hline $\begin{array}{l}\text { Pertemuan ke-3 } \\
28 \text { Juli } 2018\end{array}$ & $\begin{array}{l}\text { Pemantapan } \\
\text { Kegiatan }\end{array}$ & $\begin{array}{l}\text { Pengevaluasian tentang Penyusunan } \\
\text { Materi Pelatihan dan Penentuan } \\
\text { Waktu Pelaksanaan Abdimas }\end{array}$ & Tim Abdimas dan Mitra \\
\hline $\begin{array}{l}\text { Pertemuan ke-4 } \\
18 \text { Agutus } 2018\end{array}$ & $\begin{array}{l}\text { Pelaksanaan } \\
\text { Pelatihan }\end{array}$ & $\begin{array}{ll}\text { - } & \text { Penginformasian tentang } \\
\text { - } & \text { Pemanfaatan E-learning } \\
\text { - } & \text { Pendaftaran di Edmodo } \\
\text { - } & \text { Pengenalan Fitur-Fitur dan } \\
& \text { Keunggulan Edmodo }\end{array}$ & Tim Abdimas dan Mitra \\
\hline $\begin{array}{l}\text { Pertemuan ke-5 } \\
15 \text { September } 2018\end{array}$ & $\begin{array}{l}\text { Pelaksanaan } \\
\text { Pelatihan }\end{array}$ & $\begin{array}{l}\text { Pelaksanaan praktik dan simulasi } \\
\text { proses pembelajaran dengan } \\
\text { memanfaatkan fitur-fitur yang ada } \\
\text { pada Edmodo }\end{array}$ & Tim Abdimas dan Mitra \\
\hline
\end{tabular}

Metode yang digunakan dalam abdimas ini disesuaikan dengan tujuan, bentuk, dan materi kegiatan. Berdasarkan tujuan dan dengan mempertimbangkan kondisi masyarakat mitra, metode yang dipilih dan digunakan dalam abdimas ini adalah metode ceramah, tanya jawab, dialog interaktif, curah pendapat, dan praktik kerja.

\subsection{Analisis Kebutuhan}

Setelah disepakati bentuk kegiatan pelatihan, kemudian dilakukan analisis kebutuhan yang diperlukan dalam penyelenggaraan abdimas sebagaimana dapat dilihat pada Tabel 2.

Tabel 2. Analisis Kebutuhan

\begin{tabular}{clll}
\hline No. & Kebutuhan & Penggunaan & Keterangan \\
\hline 1 & Sarana dan prasarana & $\begin{array}{l}\text { Tempat pelaksanaan } \\
\text { pelatihan }\end{array}$ & SD Negeri Mulyorejo 1 Surabaya \\
\hline 2 & $\begin{array}{l}\text { Alat-alat: spanduk, meja } \\
\text { dan kursi, LCD dan layar } \\
\text { proyektor, laptop peserta, } \\
\text { mic, dan pengeras suara }\end{array}$ & - & - \\
\hline
\end{tabular}




\begin{tabular}{clll}
\hline No. & Kebutuhan & Penggunaan & Keterangan \\
\hline 3 & ATK & $\begin{array}{l}\text { Pencatatan materi } \\
\text { pelatihan oleh mitra dan } \\
\text { pembuatan lembar kerja }\end{array}$ & \\
\hline 4 & Instruktur & $\begin{array}{l}\text { Nara sumber dan pelatih } \\
\text { dalam kegiatan abdimas }\end{array}$ & $\begin{array}{l}\text { Dosen Fakultas Keguruan dan Ilmu } \\
\text { Pendidikan, Universitas Dr. Soetomo } \\
\text { Surabaya }\end{array}$ \\
\hline 5 & Modul Pelatihan & $\begin{array}{l}\text { Materi yang akan } \\
\text { disampaikan sebelum } \\
\text { praktik kerja }\end{array}$ & Materi disiapkan oleh instruktur \\
& & $\begin{array}{l}\text { Pelaksanaan pelatihan } \\
\text { terdiri atas snack, air } \\
\text { mineral/kopi, dan makan } \\
\text { siang }\end{array}$ & $\begin{array}{l}\text { Konsumsi disiapkan oleh tim abdimas } \\
\text { dibantu petugas SD Negeri } \\
\text { Mulyorejo I Surabaya }\end{array}$ \\
\hline 6 & Konsumsi & & \\
& & & \\
\hline
\end{tabular}

\section{HASIL DAN PEMBAHASAN}

Kegiatan abdimas dilakukan dalam bentuk pelatihan dan praktik. Pelatihan dilakukan dalam beberapa kali pertemuan. Adapun gambaran kegiatan pelatihan ini yaitu dilakukan dalam bentuk ceramah, diskusi, dan praktik. Pelatihan diawali dengan memberikan informasi mengenai pemanfaatan e-learning, pengenalan Edmodo, prosedur atau proses mendaftar di Edmodo, sampai pada pengenalan fitur-fitur dan keunggulan Edmodo. Berikutnya, fokus pada pengemasan konten pembelajaran, melakukan praktek dan simulasi proses pembelajaran dengan memanfaatkan fiturfitur yang ada pada Edmodo..

\subsection{Pembukaan}

Sebelum dilakukan pelatihan, pertemuan dibuka oleh ketua tim abdimas. Pada kesempatan tersebut, disampaikan tujuan pelatihan, bentuk kegiatan yang akan dilakukan, serta target yang diharapkan setelah dilakukan pelatihan. Produk akhir dari kegiatan abdimas ini adalah guru dapat memberikan informasi atau bahan ajar kepada siswanya melalui Edmodo. Pada kesempatan ini, tim abdimas FKIP Unitomo menyerahkan satu unit printer tipe HP Deskjet 1010 yang diserahkan oleh ketua tim abdimas kepada Kepala Sekolah SD Negeri Mulyorejo I Surabaya.

Pembukaan pelatihan dihadiri oleh ketua mitra yaitu Bapak Drs. Imam Supardi selaku Kepala Sekolah SD Negeri Mulyorejo I Surabaya serta para guru di SD Negeri Mulyorejo I Surabaya yang menjadi peserta kegiatan pelatihan ini. Dalam pidato sambutannya, Kepala Sekolah SD Negeri Mulyorejo I mengucapkan terima kasih kepada tim abdimas yang telah hadir di sekolah serta memberikan pelatihan kepada para guru SD Negeri Mulyorejo I Surabaya. Harapannya, semoga pelatihan ini bisa meningkatkan pengetahuan dan keterampilan para guru, khususnya penerapan pembelajaran berbasis e-learning pada siswa didik di SD Negeri Mulyorejo I Surabaya.

\subsection{Sosialisasi FKIP Universitas Dr. Soetomo}

Kegiatan abdimas ini juga merupakan kesempatan untuk memberikan informasi tentang FKIP Universitas Dr. Soetomo kepada mitra, yaitu menginformasikan program studi yang ada di FKIP Universitas Dr. Soetomo. Bagi guru di SD Negeri Mulyorejo I Surabaya yang belum bergelar sarjana dihimbau agar melanjutkan pendidikan di Universitas Dr. Soetomo tanpa harus meninggalkan kegiatan mengajarnya. Bagi guru yang sudah bergelar sarjana juga bisa melanjutkan ke program pascasarjana di Universitas Dr. Soetomo yaitu mengambil Strata 2 Teknologi Pendidikan. Dengan sosialisasi ini, diharapkan FKIP Unitomo lebih dikenal oleh masyarakat luas sebagai perguruan tinggi yang bisa dijadikan pilihan dalam menempuh atau melanjutkan studi di perguruan tinggi dengan biaya yang terjangkau dan tanpa harus meninggalkan tempat bekerja. 


\subsection{Pelatihan Penggunaan E-learning berbasis Media Sosial Edmodo}

Selama pelatihan, guru didampingi oleh instruktur dalam praktik memanfaatkan fitur-fitur Edmodo. Karena pelatihan berlangsung sejak pukul 09.00-14.00 WIB, peserta mendapatkan snack dan makan siang. Bagi guru yang sudah menyelesaikan tugasnya, diberikan sertifikat sebagai peserta pelatihan. Materi yang disampaikan dalam pelatihan ini meliputi: (1) Pengenalan Edmodo, (2) Perbedaan Edmodo dan Facebook, (3) Fitur-Fitur Edmodo, (4) Manfaat Edmodo untuk Pembelajaran, dan (5) Edmodo Aplikasi Jejaring Sosial untuk Guru dan Murid Belajar Berkolaborasi. Dokumentasi pada bagian ini dapat dilihat pada Gambar 1-Gambar 4.

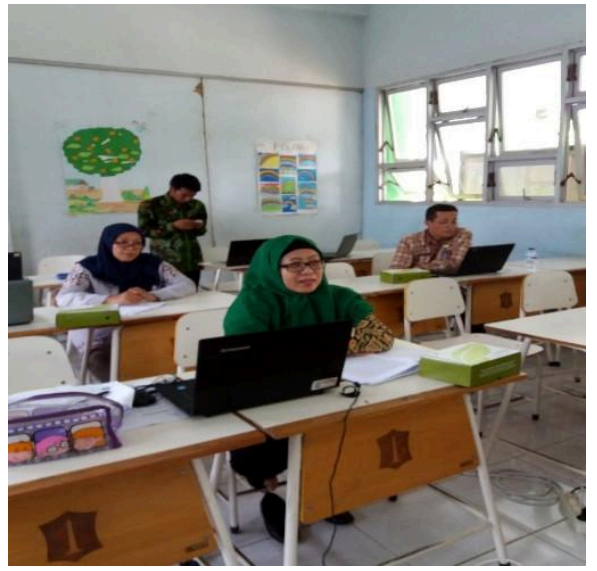

Gambar 1. Peserta saat mengikuti pelatihan Edmodo.

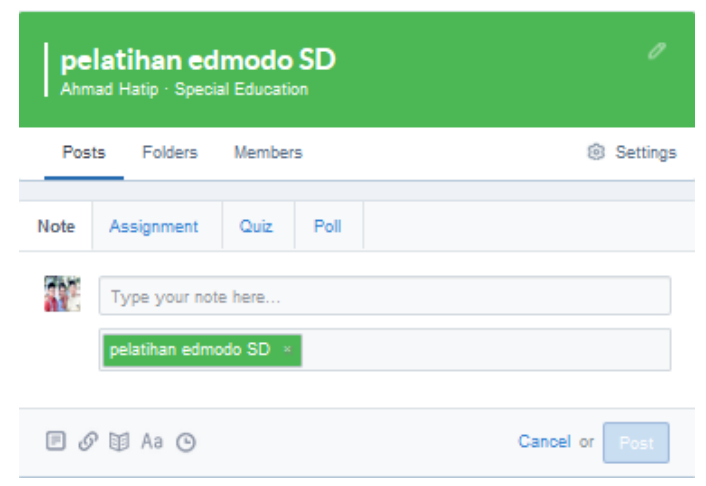

Gambar 3. Pembuatan kelas/grup saat pelatihan Edmodo.

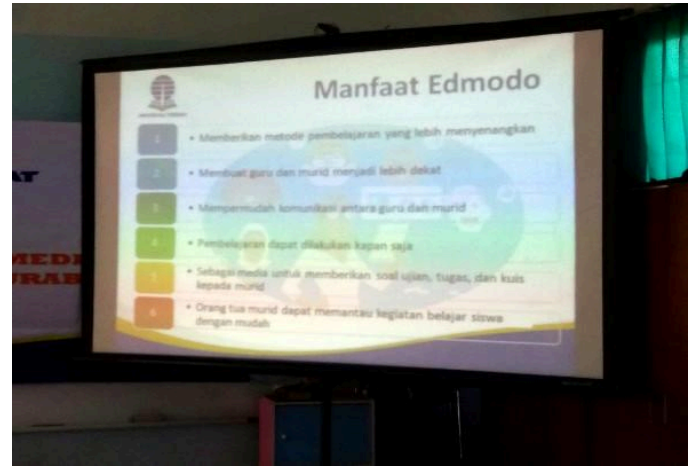

Gambar 2. Tampilan layar mengenai manfaat Edmodo.

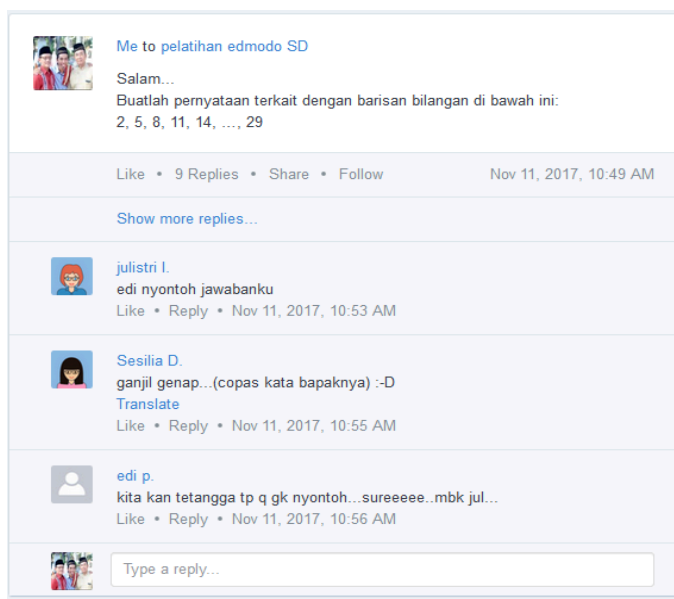

Gambar 4. Pelatihan menjawab soal terbuka berbasis masalah materi matematika untuk mengeksplor kemampuan anak sehingga setiap anak mampu memberikan jawaban yang berbeda-beda.

\subsection{Monitoring dan Evaluasi Pelatihan Edmodo}

Tabel 3. Status Monitoring dan Evaluasi

\begin{tabular}{|c|c|c|c|}
\hline \multirow[t]{2}{*}{ No. } & \multirow[t]{2}{*}{ Kegiatan yang Direncanakan } & \multicolumn{2}{|c|}{ Dilakukan? } \\
\hline & & Sudah & Belum \\
\hline 1 & Pembuatan kelas dan grup & $\checkmark$ & \\
\hline 2 & Menjawab soal terbuka & $\checkmark$ & \\
\hline 3 & Mengunduh lampiran file & $\checkmark$ & \\
\hline 4 & Mengirimkan gambar-gambar & $\checkmark$ & \\
\hline
\end{tabular}




\begin{tabular}{clcc}
\hline No. & Kegiatan yang Direncanakan & \multicolumn{2}{c}{ Dilakukan? } \\
\cline { 3 - 4 } & & Sudah & Belum \\
\hline 5 & Mengunduh gambar & $\checkmark$ & \\
6 & Memberikan tes kepada siswa melalui menu tugas & $\checkmark$ & \\
7 & Memberi reward/nilai dari tugas yang dikerjakan siswa & & $\checkmark$ \\
8 & Polling (mengetahui tanggapan siswa mengenai hal tertentu) & & $\checkmark$ \\
9 & Memantau aktivitas belajar siswa & & $\checkmark$ \\
10 & Parent Code: orang tua murid dapat memantau aktivitas belajar yang & & \\
& dilakukan anak & &
\end{tabular}

\section{KESIMPULAN}

Penyelenggaraan kegiatan abdimas "Pelatihan Penggunaan E-learning Berbasis Media Sosial Edmodo bagi Guru SD Negeri Mulyorejo I Surabaya" dapat dilaksanakan dengan baik melalaui serangkaian kegiatan pelatihan dan pendampingan. Berdasarkan keseluruhan pelaksanaan kegiatan abdimas dapat disimpulkan hasil abdimas sebagai berikut.

1) Melalui penjelasan dan dialog interaktif dengan tim abdimas, mitra dapat memperoleh pengetahuan dan keterampilan dalam mengaplikasikan media sosial Edmodo dalam pembelajaran.

2) Edmodo merupakan platform media sosial yang sering digambarkan sebagai Facebook di sekolah, yang berfungsi untuk memberikan tugas, penilaian, polling, peringatan, dan agenda kegiatan yang diberikan kepada siswa. Fitur-fitur dari Edmodo yang dapat dimanfaatkan oleh guru adalah: Assigment, File and Links, Quiz, Polling, Gradebook, Library, Awards Badges, dan Parent Code. Aplikasi ini memerlukan jaringan internet yang menyeluruh dan aktif.

3) Dorongan dan motivasi dari tim abdimas sekaligus sebagai instruktur pelatihan atau narasumber dapat menumbuhkan rasa percaya diri pada mitra untuk terus menambah wawasan dan keterampilan dalam meningkatkan mutu pembelajaran di SD Negeri Mulyorejo I Surabaya.

4) Hasil evaluasi proses yang dilakukan melalui pengamatan selama pelatihan, mitra tampak bersemangat melakukan semua kegiatan dan hadir di kelas sebelum kegiatan dimulai. Evaluasi akhir pelatihan menunjukkan bahwa secara umum mitra merasa puas dan senang memperoleh pengetahuan dan keterampilan selama pelatihan. Materi dari pelatihan sangat membantu dan bisa dimanfaatkan dalam mengelola pembelajaran di SD Negeri Mulyorejo I Surabaya. Penilaian dari mitra (Kepala Sekolah), kegiatan abdimas FKIP Unitomo memotivasi para guru untuk terus menambah wawasan dan perlu ditindaklanjuti dengan kegiatan pelatihan lanjutan.

5) Semua kegiatan yang direncanakan sudah tercapai sekitar $80 \%$. Ada beberapa yang belum tercapai, di antaranya: polling, memantau aktivitas belajar siswa, dan parent code, yaitu orang tua siswa memantau aktivitas belajar yang dilakukan anak.

\section{DAFTAR PUSTAKA}

Basori. (2013). Pemanfaatan Social Learning Network "Edmodo" dalam Membantu Perkuliahan Teori Bodi Otomotif di Prodi PTM JPTK FKIP UNS. JIPTEK., VI(2).

Hidayat, W. (2014). Pengguna Internet Indonesia Nomor Enam Dunia. EMarketer.Com, pp. 6-11. https://doi.org/10.3847/0004-637X/826/2/213

Indonesia, A. P. J. I. (2015). Profil Pengguna Internet Indonesia. Jakarta: Puskakom UI.

Mutia, I. (2013). KAJIAN PENERAPAN E-LEARNING DALAM PROSES, 6(4), 278-289.

Suriadhi, G. (2014). Pengembangan E-learning Berbasis Edmodo pada Mata Pelajaran IPA Kelas VIII di SMPN 2 Singaraja. Journal Edutech, 2(1).

Yazdi, M. (2012). E-Learning Sebagai Media Pembelajaran Interaktif Berbasis Teknologi Informasi. Jurnal Ilmiah Foristek, 2(1), 143-152. 